\begin{abstract}
$@ \oplus \Theta$
Jurnal Terapan Manajemen dan Bisnis is licensed under

A Creative Commons Attribution-NonCommercial 4.0 International License.
\end{abstract}

\title{
INTERNAL AUDIT AND LEADERSHIP: HOW TO IMPROVE PRODUCTIVITY SERVICE ON THE ISLAMIC RURAL BANK HAVE TO USE CAPITAL
}

\author{
Tulus Suryanto ${ }^{1)}$, Effendi ${ }^{2)}$, Apun Syaripudi ${ }^{3)}$
}

1) Universitas Islam Negeri Raden Intan Lampung, Lampung, Indonesia E-mail: tulus@iainradenintan.ac.id

2) Universitas Islam Negeri Raden Intan Lampung, Lampung, Indonesia E-mail: co.efendi@radenintan.ac.id.

3) Universitas Islam Negeri Raden Intan Lampung, Lampung, Indonesia E-mail: apunsyaripudin@gmail.com

\begin{abstract}
This study investigates whether the Internal Audit and Leadership significant effect to the productivity of banking services on islamic rural bank Bandar Lampung in partially and simultaneously. The approach used in this study is a qualitative and quantitative analysis. The incoming data is analyzed and tested by multiple linear regression. Before being tested by multiple linear regression, first tested by using validity and reliability test, to measure and test the questionnaire given to respondents, is quite valid and reliable. Leadership significant effect on productivity services in Islamic Rural Banks, by $19.3 \%$. Internal Audit significant effect on productivity services at the Islamic Rural Bank, by 59.6\%. Simultaneously testing indicate that the Leadership and Internal Audit jointly significant effect on productivity services in the Sharia Rural Banksby $78.9 \%$. As for the remaining $21.1 \%$ influenced by other factors. This study contributes when leadership and internal audit plays together will be able to increase the productivity services inIslamic rural bank significantly. The results of this study can be used by management in improving the quality of human resources in Islamic rural bank. Needed good leadership: making quick decisions, always motivate employees or subordinates, always creative and innovate, communicate with employees or subordinates, a clear division of authority.
\end{abstract}

Keywords: Internal Audit, Leadership, Productivity, Service, Islamic Rural Banks.

\section{Introduction}

In the context of the company's operational management and sustainable in the long term, the role of management is a very factor important. In this case the role of management, especially human resource management have a central position. It was based on the idea that human resource is a key element in creating and realizing business opportunities.In the context of empowerment of human resources in order to produce a good service productivity, it needs to be supported by factors of leadership and the existing Internal Audit in a company. Because without the leader's role as a driver running of the organization of the 
company, the service employee productivity will weaken. So that customers / consumers feel less satisfied with the service of the bank and customer confidence will decline.

Therefore, leaders are essential to the effectiveness of the organization and members. Leaders are expected to direct, develop and not turn of creativity of employees to achieve organizational goals. Times change, challenges, technology, situation and conditions of competition requires the leader to be more intelligent in act by considerations from different perspectives in order to anticipate change, manage the organization and empower members of the organization. Various phenomena requires leadership potential who have more power in order to increase the productivity of service. The concept of leadership became one of the alternatives considered effective enough to create a good Internal Audit in the company so as to create a good service productivity of the employee and ultimately the public / customers continue to believe in the bank.

Therefore, the end of the estuary in the process of organizational management in the banking sector is public confidence in the bank. Customer or consumer confidence that is the one of the important criteria to measure the reliability of a bank. This also applies to other business organizations. Belief, in this case can mean widely, especially in terms of the trust to manage the business in a professional and accurate. In directing to gain trust from clients, an enterprise services, including banking, require reliable tips from activities involving service. After all a product of superior services company, without superior service can hardly be expected to be the achievement of the company to survive and make a profit. Good service to customers is the most important factor that determines the success of a business venture within an organization or company, the more that is engaged in banking services.

Awareness of the importance of the consumer has been the driving force in the efforts of all companies that have high ambitions. "FIRST interests of consumers, the consumer is king", is now seen as a way to win the competition in the business world (Hopson \& Scally, 1995: 51). Quality services to customers by a company will bring the impact of growing customer confidence to the company. A trust will be formed if the internal management of a company is able to direct and produce reliable beings that have a high ability to serve consumers / customers. Achieve the objectives of the company, general corporate leaders or managers will face problems due to the complexity of the company's activities. This makes the leader can not directly oversee the company's activities, to have to delegate some tasks, authority and of responsibility to others.

Decision makers understanding of the role of corporate internal audit is a must. The role of internal audit is necessary, because the internal audit is an independent part, which is prepared in the company to carry out the function of inspection, control and the existence of an internal audit aimed at improving the performance of the company (Hiro Tugiman, 2000: 4). The success of the auditor in performing the audit and provide an opinion of course not separated from the auditor's behavior as the executor of the audit. Research conducted by Suryanto T (2016) discovered the role of internal audit in the implementation of internal activity can reduce an aberration or fraud is intentional behavior or violations outside of the rules and procedures performed by the executor.

In an effort to realize an organization would require the availability of a good internal audit, for the creation of a process of internal control is good too. The problem that then arises concerning the role of internal audit is how big is the existence of internal audit in providing added value (value added) for the company. Internal Audit so that leadership and is believed to be the pillar for progress and development of the company, especially in people Islamic rural Bank. 


\section{Literature Review}

Before doing further research, the researchers need to develop a theoretical framework as the basis of reasoning for a portrait from the point where researchers highlight selected issues (Nawawi, 1990: 40). Therefore, to facilitate the necessary research guidance think that the theoretical framework. In this study, which became the framework of the theory is:

\section{Leadership}

According to Achmad Suyuti is the leadership is the process of directing, guiding and influencing our thoughts, feelings, actions and behavior of others to be moved towards a specific purpose (Suyuti, 2001: 7). Another opinion suggests, leadership is a process of influencing the behavior of others to behave as would be desired (Nimran, 2004: 64).

In the opinion of Ricky Griffin, leadership is influence without the use of force is to establish goals or organizational groups, motivating towards the achievement of these goals and help to define culture groups or the Internal Audit as an attribute. Leadership is a group of characteristics possessed by an individual or a person who is seen as a leader (Ricky W.Grffin, 2004: 68). The dimensions of leadership include: determining the direction of the organization, to unite people, to encourage motivation ,improve and produce changes. Dubrin (2005: 3) argues that leadership is an effort to influence a lot of people through communication to reach the goal, the way it affects people with instructions or commands, actions that cause others to act or respond and lead to positive change, the dynamic force important motivating and coordinating organizations in order to achieve the goal, the ability to create confidence and support among subordinates so that organizational goals can be achieved. Siagian (2002: 62) argues that leadership is the ability to influence others (subordinates) such that the other person is willing to do the will of the leader though personally it might displease. Robbins (1996: 39) argues that leadership is as the ability to influence a group towards the achievement of objectives.

Leadership in principle is the ability of a leader in moving the organization, with all its available resources to achieve the goal. Leadership revealed through a questionnaire given to employees with indicators: quick decision-making, motivation, creative and innovate, the ability to communicate, delegate authority.

\section{Internal Auditing}

In the beginning, the audit is confined to the activity test, match and make a report on the fairness of the financial statements of a company. In this phase, the audit more of a role in the financial sector which aims to discover and prevent fraud as well as find and prevent errors. In line with a growing scale enterprises. Management began to feel the audit is not only limited to the financial sector alone, but extended to non-financial fields. To meet this demand, born of internal audit in addition to covering the audit on the financial sector, also include an evaluation of the adequacy of the internal control system and the quality of work execution within the company. Internal audit is an independent research function established within an organization to examine and assess the activities of the company as a service to the organization.

The term internal audit consists of two words, namely internal and auditing. When interpreted simply is an audit conducted by the internal sense by companies using employees of the company itself. This is to be distinguished from the external auditing that an audit conducted by outside parties or an independent party, in this case public accountant. 
Internal Audit is defined by the International Standards for the Professional Practice of Internal Auditing (ISPPIA) in Setyo Wibowo (2006: 1). As follows: "Internal auditing is an assurance and consulting activity are independent and objective designed to add value and improve an organization's operations. Such activities are helping organizations concerned achieve its objectives by evaluating and improving the effectiveness of risk management, control, and governancethrough regular and systematic approach.

From the above, the nature of internal auditing is an impartial assessment activities in an organization to conduct an audit within a required accounting firm, financial audit and other operations that are the foundation to assist management.

The Institute of Chartered Accountants in Australia (ICAA, 1994: 76) on the scope of the internal audit suggests: "The scope and objectives of internal audit very Widely and are dependent upon the size and structure of the entity and the requirements of its internal audit management normally however more or operates in the following are as:

a. Review of accounting systems and related internal control.

b. Examination for management of financial and operation information.

c. Examination of the economy, efficiency and effectiveness of operation Including nonfinancial controls of an organization.

This, the scope and tasks of internal audit is very widely depending on the demand of a large organization and management of the organization concerned. In general internal audit activities, among others: (1) reviewing the accounting systems and internal controls; (2) examination of the management of financial information and the company's operations; (3) an examination of whether the economic activities of companies, including non-financial controls of the organization.

Is a system of values that are believed to all employees of Bank Lampung and are guided, implemented and developed on an ongoing basis, the system serves as a control and as a reference standard to behave in the bank to achieve company goals that have been set. Internal Audit revealed through a questionnaire given to employees sharia banking credit in Bandar Lampung with indicators: education / competence, professional capabilities, scope of work, the implementation of inspection activities, the management of the internal audit section.

\section{Productivity Services}

According Sinungan question of productivity is a ratio between the output and the input or output divided by input. Feedback is often restricted by labor input, while the output is measured in physical unity of form and value (Sinungan, 2000: 12).

Another opinion says that productivity is the relationship between the outputs or outcomes with the necessary organization. Productivity can be quantified by dividing the output to input. Raising productivity can be done by improving the productivity ratio, by generating more output or better output with a certain level of resource inputs (Blecher, 2007: 241).

Meanwhile, according to Siagian said productivity is the ability to benefit from the facilities and infrastructure available to produce output (output) is optimal, even if the maximum possible (Siagian, 2002: 54). Rivianto et al (1988: 237) describes in detail the notion of productivity as follows: "Productivity can be seen from the mental attitude that always has the view that kehidudupan today should be better than yesterday and tomorrow must be better than today. Such an attitude makes people always looking for improvements and enhancements. Such a person would be compelled dynamic, creative, innovative, and open, but still critical and responsive to new ideas and changes. " 
Walter Aigner (1996: 137) formulates productivity as a process. As a process, the notion of productivity in essence implies "the will" (desire) and "effort" (effort) people to always improve the quality of life and livelihood in all fields. In connection with this opinion, Druker (1991: 87) explicitly states that productivity is an attitude. Based on these descriptions, Burnley BS said that the productivity of the service is the outcome of a company within a certain period as a result of services already offered to customers (Burnley BS, 1995: 101).

Is a productive service to customers is revealed through a questionnaire with indicators: work ethic, alignment with customers, handling issues with customers, customer satisfaction, quality and qualified employees.

Theoretical Framework

Theoretical framework proposed are as follows:

\section{LEADERSHIP $\left(X_{1}\right)$}

1.Decision-making.

2.Motivation

3.Creativeand Innovate.

4.Berkomunikas capabilities.

5.Delegation of Authority.

\section{Internal Audit (X2) \\ 1. Education / Competencies \\ 2. Ability Professionals \\ 3. Scope of Work. \\ 4. Implementation of inspection activities. \\ 5. Management of the Internal Audit}

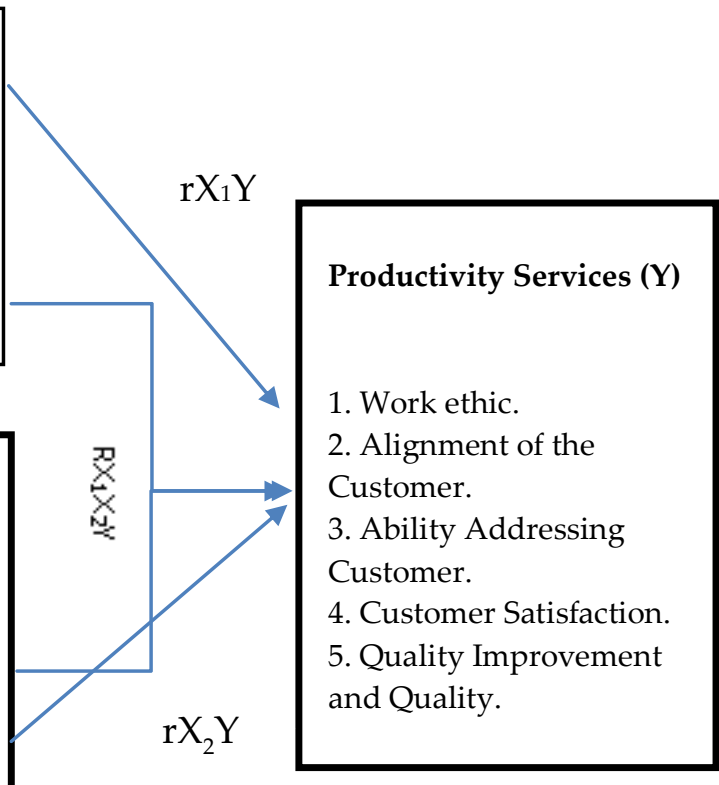

\section{Research Methods}

The methodology used is the main way to achieve the goal, to examine a series of hypotheses using the techniques and specific tools (Surachmad, 1990: 11).Type a descriptive study using survey.

\section{Variable Measurement Indicators}

Table 1 Indicators Variables $\left(\mathrm{X}_{1}\right.$ and $\left.\mathrm{X}_{2}\right)$

\begin{tabular}{llll}
\hline NO & Variable & \multicolumn{1}{c}{ Indicators } & Measurement \\
\hline 1 & & 1. Quick decision making & Likert Scale \\
& Leadership & 2. Motivation & 3 until 1 \\
& $\left(\mathrm{X}_{1}\right)$ & 3. Creative and innovate & \\
& & 4. Ability to communicate & \\
& & 5. Delegation of Authority & Likert Scale \\
2 & 1. Education / Competencies & 5 until 1 \\
& 2. Ability Professionals & \\
& Internal Audit & 3. Scope of Work. & \\
& $\left(\mathrm{X}_{2}\right)$ & 4. Implementation of inspection activities. & \\
& & 5.Manajemen Internal Audit Section &
\end{tabular}


Table 2 Indicator Dependend Variable (Y)

\begin{tabular}{llll}
\hline NO & \multicolumn{1}{c}{ Variable } & \multicolumn{1}{c}{ Indicator } & Measurement \\
\hline 1 & & 1. Work ethic & Likert Scale \\
& Productivity Services & 2. Alignment with customers & 5 until 1 \\
& 3. Ability to handle problems & \\
& & 4. Customer Satisfaction & \\
& 5. Quality Improvement and Quality & \\
\hline
\end{tabular}

Method of collecting data

The data collection method, in a way: This method is used for data retrieval leadership, Internal Audit and productivity that exist in Islamic Banking Industry BPR Syariah Particularly in Bandar Lampung. This questionnaire is intended to obtain descriptive data to test hypotheses and study models. To obtain the data were used questionnaires that are closed are questions that made such that the respondent is limited in giving an answer to a few alternatives only or to one answer (Nasir, 1988: 250).

Calculation of percentage descriptive use the following formula:

$$
\%=\frac{n}{N} \times 100 \%
$$

Where,

$\mathrm{n}=$ Total score of respondents' answers

$\mathrm{N}=$ Number of maximum score

$\%=$ Percentage value $($ Ali, 1984: 184)

\section{Interview Method}

The interview method for the data retrieval process directly with employees and leaders SRB SRB Agro Business Partners and Bandar Lampung.

\section{Population}

Population is the generalization region consisting of objects or subjects that have certain qualities and characteristics defined by the researchers to learn and then drawn conclusions (Sugiyono, 2001: 90). The population in this study are all leaders and employees, credit perbanankan sharia in Bandar Lampung. So that in find there are two (2) banks, namely: PT. SRB Agro Business Partners and PT. SRB Bandar Lampung. This research was conducted for all of the total population. So this research is called the study population / census.

\section{Analysis Method}

The method of analysis aimed to test the hypothesis in order to draw conclusions. Analysis of the data used in this study is a qualitative and quantitative analysis. The incoming data is analyzed and tested by multiple linear regression. Before being tested by multiple linear regression tested beforehand using validity and reliability test, to measure and test the questionnaire given to respondents, is quite valid and reliable. Valid is a measure that indicates the level of reliability or validity of a measuring instrument, while reliable is keajekan (consistency) research data collection tool (Riduwan, 2005: 1). 


\section{Validity test}

Validity is a measure that indicates the levels of validity or validity of an instrument (Arikunto, 2006: 160). Validity is used to measure whether or not a legitimate or valid questionnaires. A questionnaire considered valid if the questions on the questionnaire were able to reveal something that will be measured by the questionnaire. So the validity want to measure whether the questions in the questionnaire which we have created can really measure what we measure (Faith Ghozali, 2005: 45).

Test validity can be done by performing the correlation between the scores of the questions with a total score of the construct or variable. By comparing the value of $r$ is calculated by the value of $r$ table. Doing bivariate correlation between the respective indicator scores (Faith Ghozali, 2005: 46). Testing the validity of using the formula Pearson product moment correlation (Singarimbun, 1995: 137), with a minimum requirement valid $r>30 \%$. In testing the validity of the instrument used product moment correlation formula proposed by Pearson as follows:

$$
\text { rhitung }=\frac{N \cdot \sum X Y-\left(\sum X\right)\left(\sum Y\right)}{\sqrt{N \cdot \sum X^{2}-\left(\sum X\right)^{2}} \sqrt{N \cdot \sum Y^{2}-\left(\sum Y\right)^{2}}}
$$

Information:

rcalculate $=$ correlation coefficient

$\mathrm{N} \quad=$ Number of Subjects / respondent

$\mathrm{X} \quad=$ score item

$\mathrm{Y} \quad=$ the total score

$\Sigma X Y \quad=$ Number of instruments $\mathrm{X}$ multiplied by the numberInstruments $\mathrm{Y}$.

$\Sigma X 2=$ sum of squares criterion $X$

$\Sigma Y 2=$ sum of squares of $\mathrm{Y}$

(Arikunto, 2006: 162)

The calculation result rhitung consulted with prices criticism $r$ product moment with significance level of $5 \%$. If the price $\mathrm{r}_{\text {count }}>$ rtable it is said about the items were valid.

\section{Reliability test}

Instrument reliability refers to an understanding that something insrumen can be trusted to be used as a means of collecting data for the instrument is good (Arikunto, 2006: 170). While reliability testing using the formula of Alpha Croanbach with $r>0.60$ (Arikunto, 2006: 180). To test the reliability of the instrument, can be used internal reliability test were obtained by analyzing the data and a test result. Questionnaire reliability test results further research in consultation with prices $r$ product moment on a significant level of $5 \%$. If the price $r>$ rtable, the instrument said to be reliable and vice versa if $r<$ rtable, the instrument is said to be unreliable.

\section{Regression Test Analysis}

Testing the hypothesis in this study using multiple linear regression analysis. Regression analysis is used to view the variable effect of leadership and organizational culture on productivity services. Multiple linear regression formula as follows:Information :

$$
\mathrm{Y}=\mathrm{a}+\mathrm{b}_{1} \mathrm{X}_{1}+\mathrm{b}_{2} \mathrm{X}_{2}+\ldots \ldots \ldots \ldots \ldots \ldots \ldots \ldots
$$




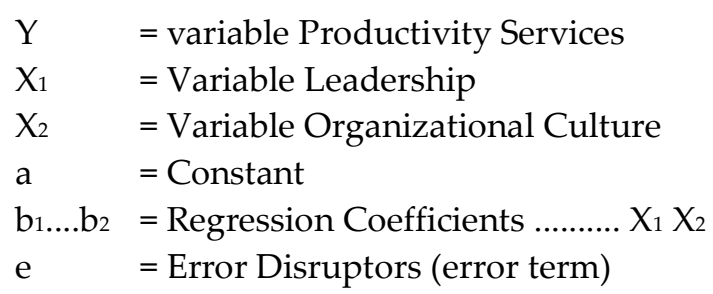

(Sugiyono, 2003: 243)

\section{Hypothesis testing}

To determine the influence of leadership and organizational culture variables on the productivity of the service, use:

\section{Simultaneous Test (Test F)}

Simultaneous test is intended to determine whether all of the independent variables have the same effect on the dependent variable. Tests were conducted using test $\mathrm{F}$. If $\mathrm{F}_{\text {count }}>$ $F_{\text {table }}$ then reject the null hypothesis $\left(\mathrm{H}_{\mathrm{o}}\right)$ and accept the alternative hypothesis $\left(\mathrm{h}_{\mathrm{a}}\right)$, which means that together have an effect on the dependent variable (Algivari, 2000: 71). In this case the influence of $X_{1}$ and $X_{2}$ to $Y$. Formula $\mathrm{F}$ test (simultaneous test), as follows:

$\mathrm{R}^{2}(\mathrm{n}-\mathrm{k}-1)$

Fhit $=\mathrm{K}\left(1-\mathrm{R}^{2}\right)$

Information :

$\mathrm{F}_{\text {count }} \quad=$ Testing Significant coefficient double

$\mathrm{R} \quad=$ Multiple correlation coefficient

$\mathrm{K}=$ Number of independ- ent variables

$\mathrm{N} \quad=$ Total number of samples

Then to measure how far the ability of independent variables in explaining the dependent variable, use the formula coefficient of determination or $R_{2}$ (Setiaji, 2004: 20). In this case to determine changes in the size of variable $Y$, which is caused by changes in the variables $X_{1}$ and $X_{2}$. The formula coefficient of determination $r_{2}=X 100 \%$.

\section{Partial test ( $t$ test)}

To find out partially independent variables affect the $\mathrm{Y} X 1$ and $\mathrm{X} 2$ independent variables affect the $\mathrm{Y}$. This test is performed using the $\mathrm{t}$ test statistic, the decision-making criteria as follows:

- Ho: accepted, if $\mathrm{t}<\mathrm{t}$ table

- Ha: accepted, if $\mathrm{t}>\mathrm{t}$ table

Both tests simultaneously and partially using the degree of freedom (d.f) at $\alpha=0.05$ or $5 \%$.

\section{Results and Discussion}

Results of Quality Test Instruments

Test the quality of instruments intended to determine whether the instrument as a means of collecting data in this study meets the criteria of validity and reliability. 


\section{Validity of Test Results}

Validity test used in this research is to use the technique of product moment. An instrument is said to be valid if the test results obtained by the correlation between the grains with a positive and significant factor is below 0.05 in Table 3 below present the results of testing the validity:

Table 3 Validity of Test Results

\begin{tabular}{lcccc}
\hline \multicolumn{1}{c}{ Variable } & Item & r count & Sig & Information \\
\hline Leadership $\left(\mathrm{X}_{1}\right)$ & 1 & $0,987^{* *}$ & 0,000 & Valid \\
& 2 & $0,987^{* *}$ & 0,000 & Valid \\
& 3 & $0,987^{* *}$ & 0,000 & Valid \\
& 4 & $0,947^{* *}$ & 0,000 & Valid \\
& 5 & $0,679^{* *}$ & 0,000 & Valid \\
Internal Audit $\left(\mathrm{X}_{2}\right)$ & 1 & $0,727^{* *}$ & 0,000 & Valid \\
& 2 & $0,618^{* *}$ & 0,000 & Valid \\
& 3 & $0,664^{* *}$ & 0,000 & Valid \\
& 4 & $0,780^{* *}$ & 0,000 & Valid \\
Productivity Services(Y) & 5 & $0,698^{* *}$ & 0,000 & Valid \\
& 1 & $0,648^{* *}$ & 0,000 & Valid \\
& 2 & $0,771^{* *}$ & 0,000 & Valid \\
& 3 & $0,793^{* *}$ & 0,000 & Valid \\
& 4 & $0,768^{* *}$ & 0,000 & Valid \\
& 5 & $0,714^{* *}$ & 0,000 & Valid \\
\hline
\end{tabular}

Note: ${ }^{*}$ : Not significant

** : Significant

Source : the attachment $9,10,11$

Based on Table 3 it can be seen that all the questions had a positive correlation coefficient and has a significance value below 0.05 so that all the questions be valid.

Reliability Test Results

Reliability test used in this study was Cronbach's Alpha technique. A questionnaire can be said to be reliable if it has more than 0.60 alpha (Anwar, 1997).

Reliability test results are presented in Table 4 below:

Table 4 Results of Test Reliability Research Variables

\begin{tabular}{lcc}
\hline \multicolumn{1}{c}{ Variable } & Alpha & Information \\
\hline Leadership $\left(\mathrm{X}_{1}\right)$ & 0,956 & Reliabel \\
Internal Audit $\left(\mathrm{X}_{2}\right)$ & 0,707 & Reliabel \\
ProductivityServices $(\mathrm{Y})$ & 0,684 & Reliabel \\
\hline
\end{tabular}

Source: Appendix 12,13,14

From Table 4 it can be seen that all the questions have a larger alpha value of 0.60 so that it can be concluded that the measuring instrument is deemed reliable. 


\section{General Description of Respondents}

The data used in this study is that its collection of primary data done by distributing questionnaires to employees and managers on sharia banking credit in Bandar Lampung. Bandar Lampung is recorded to have two (2) banking lending sharia namely: PT Bank Rakyat Syariah Perkeriditan Bandar Lampung and PT Bank Rakyat Argo Perkriditan Business Partners. The results of questionnaires as much as 58 copies, was collected as many as 58 copies and all of them deserve to be analyzed because it has been filled completely.

Description of Respondents by Gender

Table 5 Respondents by Gender

\begin{tabular}{ccc}
\hline Gender & $\Sigma$ & $\%$ \\
\hline Male & 36 & $62,1 \%$ \\
Female & 22 & $37,9 \%$ \\
$\sum$ & 58 & $100 \%$ \\
\hline
\end{tabular}

Source: Processed Data, 2016

Based on the above table it appears that male respondents amounted to $62.1 \%$ of the total 58 respondents who participated in this study. While female respondents were 22 respondents, or $37.9 \%$ of total respondents.

Description of Respondents by Age

Table 6 Respondents by Age

\begin{tabular}{ccc}
\hline AGE & $\sum$ & $\%$ \\
\hline$<35$ years & 18 & $31 \%$ \\
$>=35$ years & 40 & $69 \%$ \\
$\sum$ & 58 & $100 \%$ \\
\hline
\end{tabular}

Source: Processed Data, 2016

Based on the above table it appears that respondents under 35 years of age and $31 \%$ of the total 58 respondents who participated in this study. While respondents age 35 or older by 40 respondents or $69 \%$ of total respondents.

Description of Respondents by Job Division / Position

Table 7 Respondents by Job Division / Position

\begin{tabular}{lcc}
\hline \multicolumn{1}{c}{ Position } & $\Sigma$ & $\mathbf{\%}$ \\
\hline Assistant manager & 2 & $3.4 \%$ \\
Account Officer & 7 & $12.1 \%$ \\
Supervisor & 6 & $10.3 \%$ \\
Teller & 11 & $19 \%$ \\
Customer service & 4 & $6,9 \%$ \\
Inspector & 4 & $6,9 \%$ \\
Logistics & 1 & $1,7 \%$ \\
Secretariat & 6 & $10.3 \%$ \\
Administration & 3 & $5,2 \%$ \\
Clearing officers & 1 & $1,7 \%$
\end{tabular}


Jurnal Terapan Manajemen dan Bisnis

Volume 4 Number 1 March 2018. Page 93-106

e-ISSN: 2477-5282 p-ISSN: 2599-3127

\begin{tabular}{lcc}
\hline \multicolumn{1}{c}{ Position } & $\Sigma$ & $\%$ \\
\hline Administrative assistant & 2 & $3.4 \%$ \\
Security & 7 & $12,1 \%$ \\
Office boy & 1 & $1,7 \%$ \\
Driver & 3 & $5,2 \%$ \\
Amount & 58 & $100 \%$ \\
\hline
\end{tabular}

Source: Processed Data, 2016

Description of Respondents by Work Period

Table 8 Respondents by Work Period

\begin{tabular}{lcc}
\hline \multicolumn{1}{c}{ Working Period } & $\Sigma$ & $\%$ \\
\hline$<5$ year & 8 & $13.8 \%$ \\
5 until 10 year & 10 & $17.2 \%$ \\
11 until 15 year & 23 & $39.7 \%$ \\
$>16$ year & 17 & $29.3 \%$ \\
Amount & 58 & $100 \%$ \\
\hline
\end{tabular}

Source: Processed Data, 2016

Description of Respondents by Education

Table 9 Respondents by Education

\begin{tabular}{ccc}
\hline Education & $\Sigma$ & $\%$ \\
\hline High School & 15 & $25,9 \%$ \\
Diploma Degree & 25 & $43,1 \%$ \\
Bachelor Degree & 17 & $29,3 \%$ \\
Master Degree & 1 & $1,7 \%$ \\
Amount & 58 & $100 \%$ \\
\hline
\end{tabular}

Source: Processed Data, 2016

Based on the above table it appears that the respondents were high school education of $25.9 \%, 43.1 \%$ Diploma, Bachelor's and master's $29.3 \% 1.7 \%$ of the total 58 respondents who participated in this study.

Description of Respondents by Status of Employees

Table 10 Respondents by Status of Employees

\begin{tabular}{ccc}
\hline Employees Status & $\Sigma$ & $\%$ \\
\hline Permanent employees & 45 & $77,6 \%$ \\
Contract employees & 13 & $22,4 \%$ \\
Others & 0 & 0 \\
Amount & 58 & $100 \%$ \\
\hline
\end{tabular}

Source: Processed Data, 2016

Based on the above table it appears that the respondents whose status of employees remained at $77.6 \%, 22.4 \%$ Contract Employee of the total 58 respondents who participated in this study. 


\section{Hypothesis testing}

Testing the hypothesis in this study using a multiple linear regression analysis with the help of a computer program package SPSS version 13 for Windows. With this test we can find out the regression equation and the effect of each variable, either individually or in combination or partially or simultaneously to variable Leadership and Internal Audit Services to productivity on Sharia Rural Banks in Bandar Lampung.

Table 11 Summary of Results of Regression Calculation

\begin{tabular}{lccccc}
\hline \multicolumn{1}{c}{ Variabel Penjelas } & $\begin{array}{c}\text { Unstandardized } \\
\text { Coefficients }\end{array}$ & $\begin{array}{c}\text { Standardized } \\
\text { Coefficients }\end{array}$ & $\mathrm{t}$ & Sig & Keterangan \\
\hline Kepemimpinan $\left(\mathrm{X}_{1}\right)$ & .123 & .193 & 1,872 & 0,001 & Signifikan \\
Audit Internal & .244 & .596 & 5,776 & 0,000 & Signifikan \\
$\mathrm{R}=0,888$ & & & & & \\
$\mathrm{R}$ Square $=.789(78,9)$ & & & & & \\
Sig.F Change $=.000$ & & & & & \\
F Change $=21,42$ & 15.909 & & & & \\
Constant (a) & & & & & \\
\hline
\end{tabular}

Source: Appendix 15

The calculation above regression equation as follows:

$$
\begin{aligned}
\mathrm{Y} & =\mathrm{a}+\mathrm{b} 1 \mathrm{x} 1+\mathrm{b} 2 \mathrm{X} 2 \\
& =15.909+0,123 \mathrm{X} 1+0,244 \mathrm{X} 2
\end{aligned}
$$

Where:

$\mathrm{Y}=$ Productivity Services

$\mathrm{a}=$ Constant of 15.909, meaning that if the leadership (X1) and the Internal Audit is 0 , then the productivity of service $(\mathrm{Y})$ is positive is 15.909 .

$\mathrm{b} 1=$ regression coefficient of +0.123 positive leadership variable, meaning that if the other independent variables fixed and leadership rose 1 point, then the productivity of service $(\mathrm{Y})$ will increase +0.123 .

b2 = regression coefficient variable positive at +0244 Internal Audit, meaning that if the other independent variables fixed and Internal Audit rose 1 point, then the productivity of service (Y) will be increased by +0.244 .

\section{First Hypothesis Testing}

Effect of Leadership on Productivity Services

variable $(X 1)$ has a positive beta coefficient of +0.123 with significant value $0.001<a$ (0.05), meaning the leadership of positive and significant impact on the productivity of the service. The amount of influence partially on the leadership factor of $19.3 \%$ of service productivity. Leadership means factors will affect productivity improvement services Islamic Rural Bank in Bandar Lampung.

\section{Second Hypothesis Testing}

Effect of Internal Audit of the Productivity Services

Internal Audit variables have a positive beta coefficient of +0.244 with significant value $0,000<\mathrm{a}(0.05)$. The amount of influence factors partially on the Internal Audit service productivity by $59.6 \%$. Internal audit means positive and significant impact on the productivity of the service. 


\section{Third Hypothesis Testing}

Influence Leadership and Internal Audit of the Productivity Services

Table 11 shows the significant value of $0.000 \mathrm{~F}<\mathrm{a}(0.05)$, means leadership and Internal Audit simultaneously significant effect on the productivity of service. To see the effect of it is combined / simultaneous with R Square see the numbers in the table above. The amount of $\mathrm{R}$ is the 0888 figure. If you entered the formula coefficient of determination (CD), as follows:

$$
\begin{aligned}
\mathrm{CD} & =\mathrm{r} 2 \times 100 \% \\
& =(0888 \times 0888) \times 100 \% \\
& =0.789 \times 100 \% \\
& =78.9 \%
\end{aligned}
$$

The figure has the intention that the influence of Leadership and Internal Audit are combined / simultaneous amounted to $78.9 \%$. As for the remaining $21.1 \%(100 \%-78 \%)$ influenced by other factors or variables other than the concept of the study.

\section{Conclusion}

Based on test results influence the Leadership and Internal Audit Services Productivity in Islamic Rural Bank in Bandar Lampung, it can be deduced as follows:

1. Leadership significant effect on productivity performance in the Islamic Rural Bank Leadership amount of influence on the productivity performance of $19.3 \%$.

2. Internal Audit Services significantly influence productivity at Islamic Rural Bank. The amount of influence on the productivity of Internal Audit Services by 59.6\%.

3. The test simultaneously showed that the Leadership and Internal Audit jointly significant effect on productivity performance in the Islamic Rural Bank. The magnitude of the effect of a combined / simultaneous amounted to $78.9 \%$. As for the remaining $21.1 \%$ influenced by other factors.

\section{References}

Algifari. (2000). Analisis Teori Regresi Teori Kasus dan Solusi. Yogyakarta: BPFF.

Arikunto, Suharsini. (2006). prosedur penelitian Suatu Pendekatan Praktek, Edisi Revisi VI. Jakarta: Rineka Cipta.

Bennis, Warren. (2005). Leaders. Jakarta: PT Bhuana Ilmu Populer.

Dendawijaya, Lukman. (2001). Manajemen Perbankan. Jakarta.

Hadi, Sutrisno. (1998). Analisis Regresi. Yogyakarta: Andi Offset.

Hasselbein, Frances. (2005). On Mission and Leadership. Jakarta: PT Alek Media Komputindo.

Jogiyanto. (1993). Analisis dan Desain Sistem Informasi. Yogyakarta.

Kasmir. (2000). Bank dan Lembaga Keuangan Lainnya. Yogyakarta.

Kurniawan, Albert. (2010). Belajar Mudah SPSS untuk Pemula. Yogjakarta.

Moeljono, Djokosantoso. (2006). Audit Internal dalam Tantangan. Jakarta.

Sugiyono. (2015). Metode Penelitian administrasi. Bandung: Tarsito.

Suryanto, Tulus. (2016) . Dividend Policy, Information Technology, Accounting Reporting to Investor Reaction and Fraud Prevention. International Journal of Economic and Perspevtives, 19(1), 138-150.

Temple, A.Dele. (1991). Seni Ilmu dan Manajemen Kepemimpinan. Jakarta.

Prawirosentono, Suyadi. (1999). Kebijaksanaan Kinerja Karyawan. Yogyakarta. 
Jurnal Terapan Manajemen dan Bisnis

Volume 4 Number 1 March 2018. Page 93-106

e-ISSN: 2477-5282 p-ISSN: 2599-3127

Ricky W.Griffin. (2004). Manajemen. (EdisiBhs.Indonesia; Alih Bahasa: Gina Gania,M.B.A; Editor: Chairul Anwar, Wisnu Kristiaji, Ratri Medya). Texas A\&M Universisy. Jakarta: Erlangga.

Robbin., Stephen P. (1997). Reliabilitas dan Validitas. Yogyakarta.

Siagian, Sondang. (1998). Manajemen Sumber daya Manusia. Jakarta.

Sarwono, Jonathan. (2006). Analis Data Penelitian Menggunakan SPSS. Bandung: Andi Offset.

Sesetyo, Budi. (2010). Statistika Analisis Penelitian. Bandung: Refika Aditama. 